\title{
ERUDYCJA JAKO CEL SZKOLNEJ EDUKACJI FILOZOFICZNEJ ${ }^{1}$
}

\begin{abstract}
Streszczenie: Erudycja może być jednym z celów szkolnej edukacji filozoficznej. Nauczyciele filozofii, którzy w 2014 roku wzięli udział w ogólnopolskim badaniu nauczania filozofii w gimnazjach i szkołach ponadgimnazjalnych (w którym udało się zebrać dane od 88 proc. dyrektorów wszystkich szkół w Polsce, gdzie nauczano filozofii, oraz 79 proc. nauczycieli z tych szkół), poproszeni o wskazanie, jak ważne są ich zdaniem poszczególne cele szkolnej edukacji filozoficznej (w skali o-5), ocenili erudycję stosunkowo nisko. Mimo to przeanalizowane w artykule wyniki pokazują, że nauczyciele doceniają ją jako cel edukacji filozoficznej, co zbieżne jest $\mathrm{z}$ odpowiedziami dyrektorów. Z kolei wywiady pogłębione przeprowadzone z 15 nauczycielami i 15 dyrektorami pokazują, że zarówno jedni, jak i drudzy doceniają erudycję w głębszym sensie: taką, która nie jest wiedzą „encyklopedyczną”, lecz wiedzą dobrze zrozumianą, będącą podstawą dla rozwoju osobistego, rozwijania umiejętności oraz formułowania pytań.
\end{abstract}

Słowa kluczowe: filozofia, nauczanie filozofii, szkolna edukacja filozoficzna, erudycja, cele kształcenia, efekty uczenia się, wiedza, umiejętności.

1 Artykuł prezentuje analizę wyników Badania nauczania filozofii w gimnazjach i szkołach ponadgimnazjalnych, zrealizowanego w Instytucie Badań Edukacyjnych w ramach projektu systemowego „Badanie jakości i efektywności edukacji oraz instytucjonalizacja zaplecza badawczego", współfinansowanego ze środków Europejskiego Funduszu Społecznego. Główne wyniki badania przedstawiono w raporcie Instytutu Badań Edukacyjnych: Trepczyński i in. 2015. Autor był kierownikiem zespołu prowadzącego to badanie pod opieką merytoryczną prof. dr hab. Jolanty Choińskiej-Miki. Autor składa podziękowanie za wsparcie, współpracę oraz pomoc w prowadzeniu badania i przygotowaniu reportu prof. Choińskiej-Mice, Alinie Stanaszek, Magdalenie Grudniewskiej, Dominikowi Mytkowskiemu, Iwonie Gmaj, Krzysztofowi Bulkowskiemu, Michałowi Męzińskiemu, Paulinie Okołów, Jarosławowi Rosińskiemu oraz Marcinowi Broniszewskiemu, a także zespołowi współpracowników terenowych IBE. Wyniki badania oraz wykorzystane narzędzia są udostępniane przez IBE do użytku naukowego; odwołanie się w niniejszym opracowaniu do wyników badania odbywa się zgodnie z prawem i nie godzi w prawa osób trzecich. 


\section{Wprowadzenie}

Przyjęcie erudycji za cel edukacji jest zagadnieniem problematycznym. Erudycja jest bowiem cechą, która może budzić zarówno zdecydowanie pozytywne, jak i negatywne skojarzenia. Zgodnie $z$ definicjami słownikowymi jest ona utożsamiana $\mathrm{z}$ rozległą wiedzą ; $\mathrm{w}$ takim ujęciu jest ona czymś, co u ludzi się docenia lub za co się ich podziwia. Jednak w niektórych kontekstach może być ona uważana za pułapkę. Bywa tak m.in. w przypadku edukacji. Z jednej strony wydaje się oczywiste, że w ramach procesu dydaktycznego konieczne jest zdobywanie jak najszerszej wiedzy. Z drugiej strony teoretycy nauczania wskazują na to, że czysta erudycja jako cel edukacji to poważny błąd i że jest ona czymś innym niż wykształcenie ${ }^{3}$. Założenia takie przyjęto przy tworzeniu podstawy programowej kształcenia ogólnego, wydanej w 2008 roku (zmodyfikowanej w 2012 i 2014 roku), której twórcy starali się wśród celów kształcenia ująć nie tylko wiedzę, lecz także postawy oraz umiejętności (Marciniak 2008, s. 10) ${ }^{4}$, a także przy wprowadzonej w 2017 roku podstawie programowej dla szkół podstawowych oraz przedstawionym do konsultacji w tym samym roku projekcie podstawy programowej dla liceum i technikum, w których widoczne jest nastawienie na umiejętności ucznia ${ }^{5}$. Zmiany w tym kierunku nastąpiły również w formule egzaminu maturalnego, w zakresie egzaminu z filozofii, na co wskazuje wprost M. Szymański ${ }^{6}$.

2 Według Słownika Języka Polskiego, dostępnego w internecie, erudycja to „rozległa, wszechstronna znajomość jednej lub wielu dziedzin nauki, gruntowne wykształcenie; wiedza książkowa, oczytanie, uczoność; według internetowych słowników oksfordzkich jest to „cecha posiadania lub wykazywania się wielką wiedzą; wiedza" (Erudition, 2018b: The quality of having or showing great knowledge or learning; scholarship lub „wielka wiedza o charakterze akademickim” (Erudition, 2018a: great academic knowledge).

3 Na pogląd taki u Jeana Piageta wskazuje m.in. I. Shor, cytując następującą wypowiedź: ,jeśli celem treningu intelektualnego jest raczej kształtowanie inteligencji niż składowanie w pamięci i produkowanie raczej intelektualnych odkrywców niż jedynie erudycji, to tradycyjna edukacja wyraźnie ponosi winę za poważny brak” i uzupełniając, że ów brak to „podstawa programowa w szkołach postrzegana jako jednokierunkowa transmisja zasad i wiedzy od nauczyciela do uczniów" (1992, s. 12). Z kolei, jak zauważa H. Gajdamowicz, erudycję i wykształcenie zdecydowanie rozróżniał Bogdan Nawroczyński, przestrzegając zarazem przed wąsko pojętą erudycją, w taki oto sposób: „Jeszcze jaskrawiej zaznacza się różnica pomiędzy erudycją a wykształceniem. Nagromadzone wiadomości mogą być zewnętrznym tylko nabytkiem, jak to bywa w wypadku duchowego parweniuszostwa. Mogą one również być maską, pod którą ukrywa się barbarzyństwo lub pustka duchowa. Mogą być wreszcie bagażem, przytłaczającym wątły umysł i słabą indywidualność" (Nawroczyński 1946, s. 106; za: Gajdamowicz 2012, s. 130).

4 Triada trzech typów celów: wiadomości, umiejętności, postawy - zaznacza się w wielu częściach podstawy programowej, zob. np. Marciniak 2008, s. 15.

5 Por. cele kształcenia ogólnego w szkole podstawowej (MEN 2017b, zał. nr 2, s. 11), a także cele kształcenia ogólnego w liceum i technikum (MEN 2017a, s. 1).

6 Porównując liczbę punktów do zdobycia za poszczególne części egzaminu w kolejnych odsłonach egzaminu maturalnego z filozofii, M. Szymański odnośnie do sytuacji w 2014 roku zauważył: 
Szczególnym kontekstem dla rozważań o erudycji w edukacji jest nauczanie filozofii. Wydaje się bowiem, że od filozofa należy wymagać szerokiej znajomości pojęć, koncepcji i prądów filozoficznych, a także poglądów filozofów i tego, w jaki sposób na siebie wpływali. W skrajnym ujęciu Augusta del Noce, aby być filozofem, należy wręcz uprawiać historię filozofii, gdyż tylko dzięki niej można sensownie filozofować (szerzej: Wierzbicki 2005). Zarazem jednak zwraca się uwagę, że filozofowanie to coś innego niż znajomość historii filozofii; to raczej aktywność, polegająca na stawianiu pytań i poszukiwaniu na nie odpowiedzi, wynikająca z początkowej postawy zdziwienia (por. Pobojewska 2012, s. 13-16), co zgadza się z poglądem filozofów starożytnych, że źródłem filozofii jest właśnie zdziwienie ${ }^{7}$. Dlatego też w ramach edukacji szkolnej istnieje zagrożenie, że położenie zbyt dużego nacisku na przekazanie wiadomości z zakresu dotychczasowych ustaleń filozofów może przyćmić lub wyłączyć samo filozofowanie.

Zagadnienie miejsca erudycji wśród celów nauczania, w tym nauczania filozofii, $\mathrm{w}$ świetle powyższych uwag wydaje się - jak wskazano na początku - problematyczne i tym samym ciekawe, a ponadto - jak sądzę - warte przemyślenia, jeśli chce się świadomie kreować edukację filozoficzną. W tej sytuacji warto przyjrzeć się stosunkowi, jaki wobec erudycji jako celu nauczania filozofii mają nauczyciele filozofii oraz dyrektorzy szkół. Pozwalają na to wyniki ogólnopolskiego badania dotyczącego nauczania filozofii w gimnazjach i szkołach ponadgimnazjalnych, przeprowadzonego $\mathrm{w} 2014$ roku wśród dyrektorów i nauczycieli w większości polskich szkół, w których w roku tym lub w kilku poprzedzających go latach nauczano filozofii. Informacje te nie dostarcząją oczywiście ostatecznych odpowiedzi na postawione pytania. Mogą jednak stanowić wartościowy przyczynek do dyskusji. Celem niniejszego artykułu jest prezentacja oraz analiza danych dotyczących stosunku badanych osób do erudycji jako celu nauczania filozofii, z których większość (z uwagi na ich szczegółowość) nie została zaprezentowana w raporcie z badania, ani jak dotąd w żadnej innej publikacji.

\section{Informacje o badaniu}

\section{Cel i zakres}

Badanie nauczania filozofii w gimnazjach i szkołach ponadgimnazjalnych przeprowadził w 2014 roku zespół badaczy Instytutu Badań Edukacyjnych. Przyjęto, że

„Pokazuje to dobitnie, że czynnikami, wokół których skupiona jest ocena ucznia, jest jego umiejętność podejmowania polemiki, analizy i swobodnego korzystania z treści, które wymagają zdolności posługiwania się analizą i interpretacją, w zdecydowanie mniejszym stopniu odtwarzaniem encyklopedycznej wiedzy" (Szymański 2014, s. 195).

7 W Teajtetcie Platon pisze na ten temat następująco: „To stan bardzo znamienny dla filozofa: dziwić się. Nie ma innego początku filozofii, jak to właśnie" (155d; Platon 2002, s. 113). Arystoteles zaś twierdzi w Metafizyce, że: „Dzięki [...] dziwieniu się ludzie obecni, jak i pierwsi myśliciele zaczęli filozofować" (982b; Arystoteles 2003, s. 620). 
będzie ono miało charakter wstępny i rozpoznawczy. Jego głównym celem było ustalenie, w jakiej skali i w jaki sposób nauczana jest w polskich szkołach filozofia. Dodatkowo próbowano zdobyć informacje o celach prowadzenia edukacji filozoficznej w szkołach, uwarunkowaniach, od których zależy decyzja o wprowadzeniu do nauczania przedmiotu filozoficznego, a także na temat realizacji zakresu nauczania tego przedmiotu, wprowadzonego w 2009 roku w podstawie programowej. Na etapie przygotowywania badania wyłączono z niego szkoły podstawowe, ponieważ z informacji uzyskanych z Systemu Informacji Oświatowej wynikało, że w całej Polsce tylko w sześciu szkołach podstawowych prowadzi się zajęcia z filozofii; mogłoby więc te szkoły objąć odrębne badanie, polegające na opisaniu sytuacji w każdej ze szkół w formie studium przypadku. Na etapie projektowania badania postanowiono wyłączyć z niego przedmiot etyka. Chociaż etyka jest uznawana za część filozofii, to jednak inne problemy badawcze obejmuje przedmiot etyka, a inne filozofia, m.in. zgodnie z obowiązującymi przepisami, etykę należy wprowadzić na żądanie choćby jednego ucznia; nie występuje w jej przypadku grupa problemów związanych z rozbudowaną podstawą programową przedmiotu filozofia; istnieją natomiast dodatkowe zagadnienia związane $\mathrm{z}$ relacją między przedmiotem etyka i przedmiotem religia. Uznano więc, że nauczaniu etyki należałoby poświęcić odrębne badanie. Aby nie było w tym zakresie wątpliwości, w ankietach silnie podkreślano, że badanie nie dotyczy przedmiotu etyka.

\section{Badane osoby}

Badaniu poddano dyrektorów i nauczycieli filozofii ze szkół, w których w roku 2013/2014 lub w ciągu poprzedzających go ok. pięciu lat prowadzono zajęcia filozoficzne. Ze względu na wstępny charakter badania nie podjęto się zebrania opinii uczniów; przeprowadzenie takiego badania znalazło się w rekomendacjach kończących raport z badania. Zaproszenie do badania skierowano do wszystkich szkół, o których wiedziano, że prowadziły edukację filozoficzną. Informacje o tych szkołach pobrano z Systemu Informacji Oświatowej; równolegle poproszono kuratoria o informacje na ten temat, a ponadto przeprowadzono mailing do wszystkich szkół średnich z prośbą o zgłoszenie się, jeśli również kwalifikują się one do badania.

\section{Metoda badania}

Badanie miało charakter mieszany - zarówno ilościowy, jak i jakościowy. Poprzedzone zostało badaniem pilotażowym przeprowadzonym w ok. 10 szkołach, które pozwoliło dopracować koncepcję badania oraz narzędzia. Podstawą badania głównego były ankiety internetowe, zawierające po części pytania otwarte, odrębne dla dyrektorów i dla nauczycieli ze wszystkich szkół objętych badaniem, oraz wywiady pogłębione, przeprowadzone osobno z dyrektorami i nauczycielami w 15 szkołach (po jednym na województwo; jeden nie doszedł do skutku). Po 
telefonicznym potwierdzeniu przez szkoły chęci udziału w badaniu, zaproszenia do wypełnienia ankiety wysłano do 249 dyrektorów oraz do 248 nauczycieli (w tym do szkół, w których uczono filozofii w roku 2013/2014 - odpowiednio do 180 i 196). Stopa zwrotu w przypadku ankiet skierowanych do wszystkich dyrektorów wyniosła 83 proc., zaś w przypadku wszystkich nauczycieli - 79 proc.; biorąc zaś pod uwagę tylko szkoły, w których uczono filozofii w roku 2013/2014 - odpowiednio 88 proc. i 79 proc..

Trzecim elementem badania była debata z udziałem ekspertów - dyrektorów, nauczycieli filozofii oraz badaczy edukacji, którzy w świetle cząstkowych wyników swoimi spostrzeżeniami uzupełnili obraz nauczania filozofii w Polsce i związanej z tym problematyki.

\section{Raport i główne wyniki badania}

Na podstawie zgromadzonego materiału powstał opublikowany w 2015 roku raport pt. Nauczanie filozofii na III i IV etapie edukacyjnym, w którym zaprezentowano szczegółowo główne wyniki badania i płynące z nich wnioski i rekomendacje; nie będą więc one prezentowane w niniejszym artykule, poza tymi, które dotyczą jego tematu. Aby jednak zarysować tło dla dalszych spostrzeżeń, warto przytoczyć kilka zupełnie podstawowych danych, a mianowicie, że w roku szkolnym 2013/2014 filozofii nauczano w 196 szkołach na 14377 szkół ponadpodstawowych w całej Polsce:

- w 41 gimnazjach: w 15 gimnazjach publicznych, 26 gimnazjach niepublicznych oraz

- w 155 szkołach ponadgimnazjalnych: 116 liceach publicznych, w tym w jednym liceum artystycznym, 38 liceach niepublicznych i w jednym technikum publicznym.

Warto też nadmienić, że we wspomnianym roku szkolnym tylko w 13 proc. przypadków nauczano filozofii jako przedmiotu w zakresie rozszerzonym na IV etapie edukacyjnym (a tylko dla tak zaprojektowanego przedmiotu stworzono podstawę programową ${ }^{8}$, przewidując dla niego 240 godzin w cyklu dydaktycznym ${ }^{9}$ ). Natomiast najpopularniejszymi formami prowadzenia zajęć z filozofii okazały się: filozofia jako przedmiot uzupełniający ( 42 proc.), przedmiot filozoficzny o innej nazwie (29 proc.) i kółko zainteresowań (23 proc.).

8 Por. Rozporządzenie Ministra Edukacji Narodowej z dnia 27 sierpnia 2012 roku w sprawie podstawy programowej wychowania przedszkolnego oraz kształcenia ogólnego w poszczególnych typach szkół (Dz.U. z 2012 roku, poz. 997 ze zm.).

9 Por. Rozporządzenie Ministra Edukacji Narodowej z dnia 7 lutego 2012 roku w sprawie ramowych planów nauczania w szkołach publicznych (Dz.U. z 2012 roku, poz. 204 ze zm.). 


\section{Erudycja jako cel nauczania - wyniki}

\section{Komponent ilościowy}

Zagadnienie erudycji w komponencie ilościowym badania pojawiło się w pytaniu skierowanym do nauczycieli o cele nauczania filozofii w szkole oraz w pytaniu do dyrektorów o powody wprowadzenia filozofii do nauczania w ich szkołach. W obu przypadkach pytania były zamknięte, a erudycja została uwzględniona wśród opcji do wyboru, sformułowanych głównie na podstawie wyników badania pilotażowego.

Pytanie do nauczycieli brzmiało: „Chcielibyśmy dowiedzieć się, co Pani/Pana zdaniem, powinno być przede wszystkim celem nauczania filozofii w szkole. Przy poniższych celach proszę określić na skali o-5, jak ważny jest, wg Pani/Pana, każdy z nich. 5 oznacza, że Pani/Pana zdaniem dane cele powinny być przede wszystkim celami nauczania filozofii w szkole. Cyfry o-4 proszę wykorzystać do zróżnicować ważności pozostałych celów. Brak zaznaczenia oznacza «o»".

Respondenci przyporządkowywali cyfry od o do 5 dla celów określonych jako ogólne (twórcze myślenie, samodzielność myślenia, wrażliwość moralna, krytyczny stosunek do stereotypów, dociekliwość poznawcza, erudycja, lepsze rozumienie świata, ludzi i samego siebie), które zostały sformułowane na podstawie wspomnianego badania pilotażowego, oraz dla wszystkich celów podanych w podstawie programowej przedmiotu filozofia.

Wykres 1. Najważniejsze cele ogólne nauczania filozofii według nauczycieli filozofii (proc. nauczycieli wskazujących dany cel jako najważniejszy), $\mathrm{N}=196$

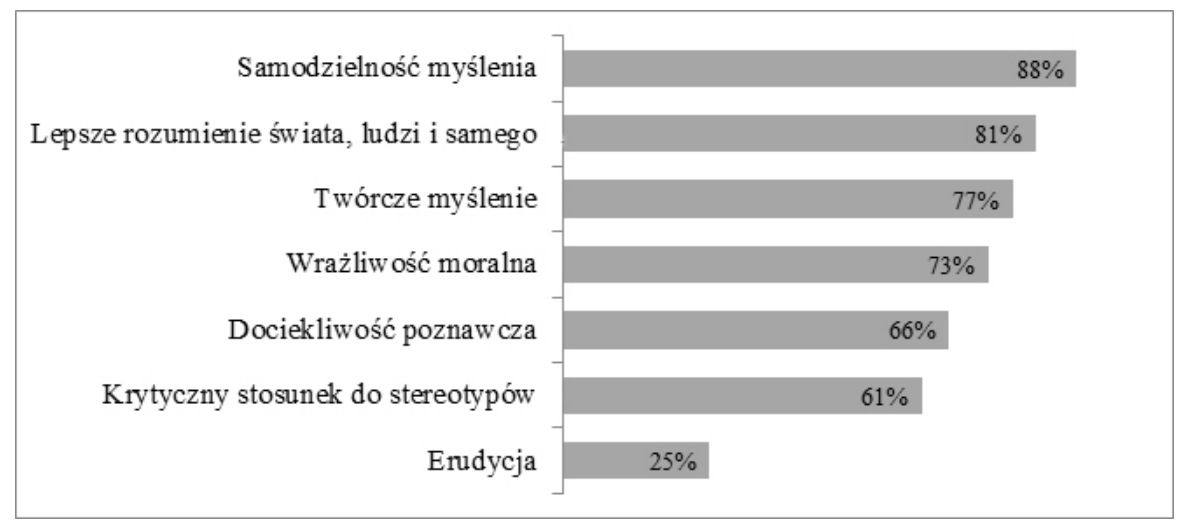

Źródło: raport IBE: Trepczyński i in. 2015.

$\mathrm{W}$ raporcie $\mathrm{z}$ badania postanowiono przedstawić liczbę wskazań o wartości "5". Uznano bowiem, że ponieważ respondenci większość propozycji uznają za cele nauczania filozofii, należy skupić się na tych propozycjach, które zdaniem respondentów „powinny być przede wszystkim celami nauczania filozofii w szkole”, 
a którym zgodnie z przytoczoną wyżej treścią pytania należy przypisać wartość "5". Wartość taką nadało erudycji 25 proc. respondentów, co na tle pozostałych celów ogólnych było najsłabszym wynikiem, co więcej, znacznie odbiegającym od pozostałych. Wyniki dla wszystkich celów ogólnych zaprezentowano na wykresie 1. Nie będą tu przedstawiane wyniki dotyczące celów zaczerpniętych z podstawy programowej. Dotyczą one bowiem poszczególnych nauczanych umiejętności i tym samym mają one inny status niż cele ogólne; nie są więc istotnym tłem dla wyników dotyczących erudycji. Dane te zaprezentowano we wspomnianym raporcie $\mathrm{z}$ badania.

Ponadto jednak warto zobaczyć, jak rozłożyły się wskazania dotyczące wszystkich przypisanych poszczególnym celom wartości. Rozkład taki zaprezentowano w tabeli 1. Danych tych (podobnie jak i danych dotyczących odpowiedzi nauczycieli przedstawionych na kolejnych wykresach) nie prezentowano do tej pory w żadnym opracowaniu.

Tabela 1. Wartości przypisywane przez nauczycieli filozofii głównym celom nauczania filozofii, $\mathrm{N}=196$ (w procentach)

\begin{tabular}{|l|c|c|c|c|c|c|c|}
\hline & brak & $\mathbf{0}$ & $\mathbf{1}$ & $\mathbf{2}$ & $\mathbf{3}$ & $\mathbf{4}$ & $\mathbf{5}$ \\
\hline Samodzielność myślenia & 0 & 1 & 0 & 1 & 3 & 9 & 88 \\
\hline $\begin{array}{l}\text { Lepsze rozumienie świata, ludzi } \\
\text { i samego siebie }\end{array}$ & 2 & 1 & 0 & 2 & 4 & 13 & 79 \\
\hline Twórcze myślenie & 1 & 1 & 0 & 3 & 6 & 13 & 77 \\
\hline Wrażliwość moralna & 1 & 1 & 1 & 5 & 4 & 17 & 72 \\
\hline Dociekliwość poznawcza & 1 & 1 & 1 & 1 & 10 & 22 & 65 \\
\hline $\begin{array}{l}\text { Krytyczny stosunek do } \\
\text { stereotypów }\end{array}$ & 1 & 1 & 2 & 3 & 8 & 25 & 61 \\
\hline Erudycja & 1 & 1 & 6 & 14 & 29 & 25 & 25 \\
\hline
\end{tabular}

Źródło: oprac. własne.

Jeśli chodzi o dokładny rozkład dla celu „erudycja”, to poza 49 respondentami ( 25 proc. ze 196), którzy uznali erudycję za jeden z głównych celów filozofii, przypisując mu wartość „, w” skali o-5, również 49 przypisało jej wartość „4”, wartość „, przypisało jej 57 respondentów, wartość „2” - 28, wartość „1” - 11, wartość „,” - 1, a ponadto jeden respondent $\mathrm{w}$ ogóle nie udzielił w tym zakresie odpowiedzi.

Warto również przyjrzeć się dodatkowym, niepublikowanym dotąd danym dotyczącym grupy ankietowanych, którzy uznali erudycję za jeden z najważniejszych celów nauczania filozofii. Podział tej grupy pod względem płci (29 kobiet i 20 mężczyzn) odpowiada podziałowi wszystkich ankietowanych (56 proc. : 44 proc). Jeśli chodzi o szkoły, w których w czasie badania uczyli respondenci, to dziewięciu 
z nich uczyło w gimnazjach, jeden w technikum, a 31 w liceach ogólnokształcących, przy czym w roku, którego dotyczyło badanie, filozofii uczono w 41 gimnazjach, w jednym technikum i w 154 szkołach ponadgimnazjalnych, z wyłączeniem techników. Rozkład respondentów, ze względu na wielkość miejscowości, w której znajduje się szkoła, również odpowiada rozkładowi wśród wszystkich ankietowanych, choć z pewnym przesunięciem na korzyść średniej wielkości miast, głównie kosztem Warszawy, co widać w kolejnej tabeli.

Tabela 2. Porównanie rozkładu wszystkich nauczycieli filozofii biorących udział w badaniu $(\mathrm{N}=196)$ i tych, którzy uznali erudycję za jeden za najważniejszych celów nauczania filozofii, według miejscowości, w której znajduje się ich szkoła (N=49) (w procentach)

\begin{tabular}{|l|c|c|c|c|c|}
\hline & $\begin{array}{c}\text { Wieś bądź } \\
\text { część } \\
\text { wiejska } \\
\text { gminy } \\
\text { miejsko- } \\
\text {-wiejskiej }\end{array}$ & $\begin{array}{c}\text { Miasta } \\
\text { do 15 tys. } \\
\text { mieszk. }\end{array}$ & $\begin{array}{c}\text { Miasta } \\
\text { od 15 do } \\
\text { 100 tys. } \\
\text { mieszk. }\end{array}$ & $\begin{array}{c}\text { Miasta } \\
\text { pow. 100 } \\
\text { tys. mieszk. } \\
\text { (bez } \\
\text { Warszawy) }\end{array}$ & Warszawa \\
\hline $\begin{array}{l}\text { Wszyscy } \\
\text { respondenci } \\
\text { (N=196) }\end{array}$ & 4 & 7 & 32 & 40 & 17 \\
\hline $\begin{array}{l}\text { Respondenci, } \\
\text { którzy uznali } \\
\text { erudycję za } \\
\text { jeden z naj- } \\
\text { ważniejszych } \\
\text { celów na- } \\
\text { uczania filo- } \\
\text { zofii (N=49) }\end{array}$ & 4 & 6 & 43 & 39 & 8 \\
\hline
\end{tabular}

Źródło: oprac. własne.

Należałoby wreszcie zwrócić uwagę na wiek respondentów ze wskazanej grupy w chwili badania; na tle wszystkich ankietowanych wygląda to następująco:

- powyżej 50 lat - $11 \mathrm{z}$ 54,

- 41-50 lat - 22 z 66,

- 31-40 lat - $11 \mathrm{z} 61$,

- poniżej 31 lat - $5 \mathrm{z}$ 12,

przy czym najmłodszy respondent z tej grupy urodził się w 1986 roku, czyli w chwili badania miał 28 lat, zaś w całej próbie najmłodszy ankietowany urodził się w 1987 roku. Procentowy udział osób, które wskazały wartość „5” dla erudycji w poszczególnych grupach wiekowych pokazano na poniższym wykresie. 
Wykres 2. Procentowy udział osób, które uznały erudycję za jeden z najważniejszych celów nauczania filozofii (wartość „””) w poszczególnych grupach wiekowych, $\mathrm{N}=196$

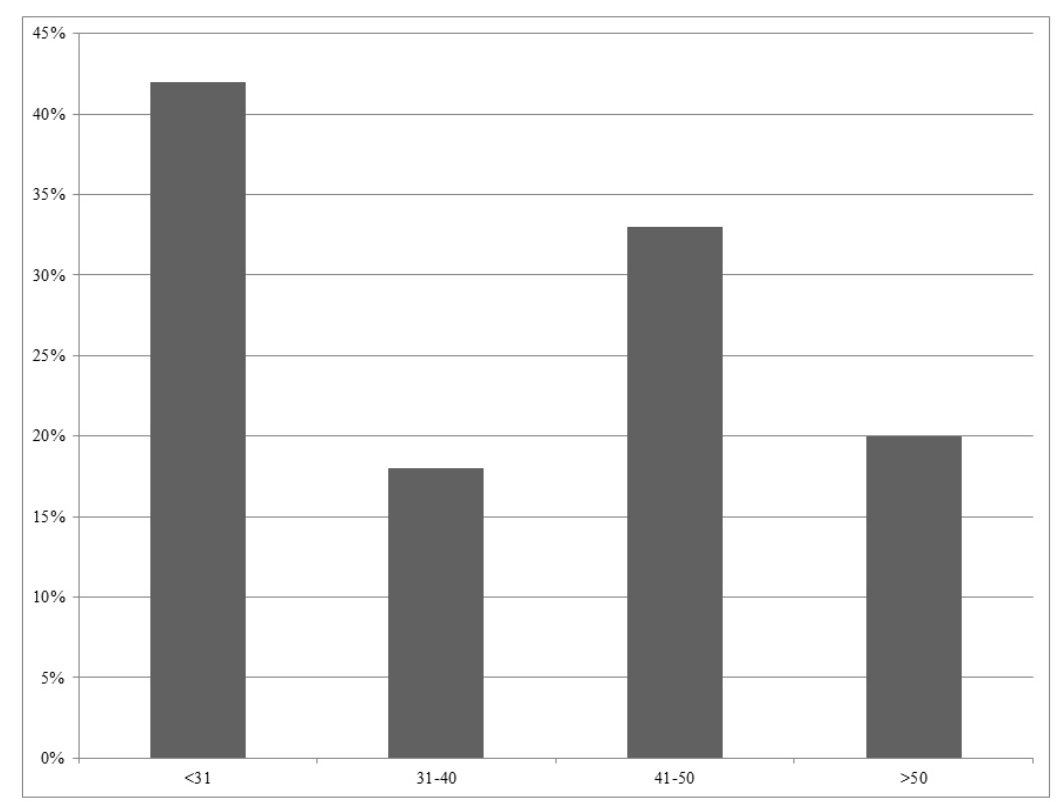

Źródło: oprac. własne.

Na koniec różnice wskazane na tym wykresie należałoby zestawić z różnicami w obrębie grup wiekowych wśród respondentów, którzy przypisali wartość ",5" pozostałym celom. Porównanie takie przedstawiono w tabeli 3. Jednak aby lepiej unaocznić różnice, porównanie to przedstawiono również na wykresie.

Tabela 3. Procentowy udział osób, które wskazywały poszczególne cele ogólne filozofii jako najważniejsze (wartość „5”) w poszczególnych grupach wiekowych, $\mathrm{N}=196$ (w procentach)

\begin{tabular}{|l|c|c|c|c|}
\hline \multicolumn{1}{|c|}{ Główne cele nauczania filozofii } & $<\mathbf{3 1}$ lat & $\mathbf{3 1 - 4 0 ~ l a t ~}$ & 41-50 lat & $>$ 50 lat \\
\hline Samodzielność myślenia & 100 & 85 & 88 & 93 \\
\hline $\begin{array}{l}\text { Lepsze rozumienie świata, ludzi } \\
\text { i samego siebie }\end{array}$ & 58 & 75 & 83 & 87 \\
\hline Twórcze myślenie & 100 & 74 & 79 & 76 \\
\hline Wrażliwość moralna & 83 & 61 & 79 & 78 \\
\hline Dociekliwość poznawcza & 75 & 57 & 70 & 70 \\
\hline Krytyczny stosunek do stereotypów & 92 & 49 & 59 & 72 \\
\hline Erudycja & 42 & 18 & 33 & 20 \\
\hline
\end{tabular}

Źródło: oprac. własne. 
Wykres 3. Procentowy udział osób, które wskazywały poszczególne cele ogólne filozofii jako najważniejsze (wartość „5”) w poszczególnych grupach wiekowych, $\mathrm{N}=196$

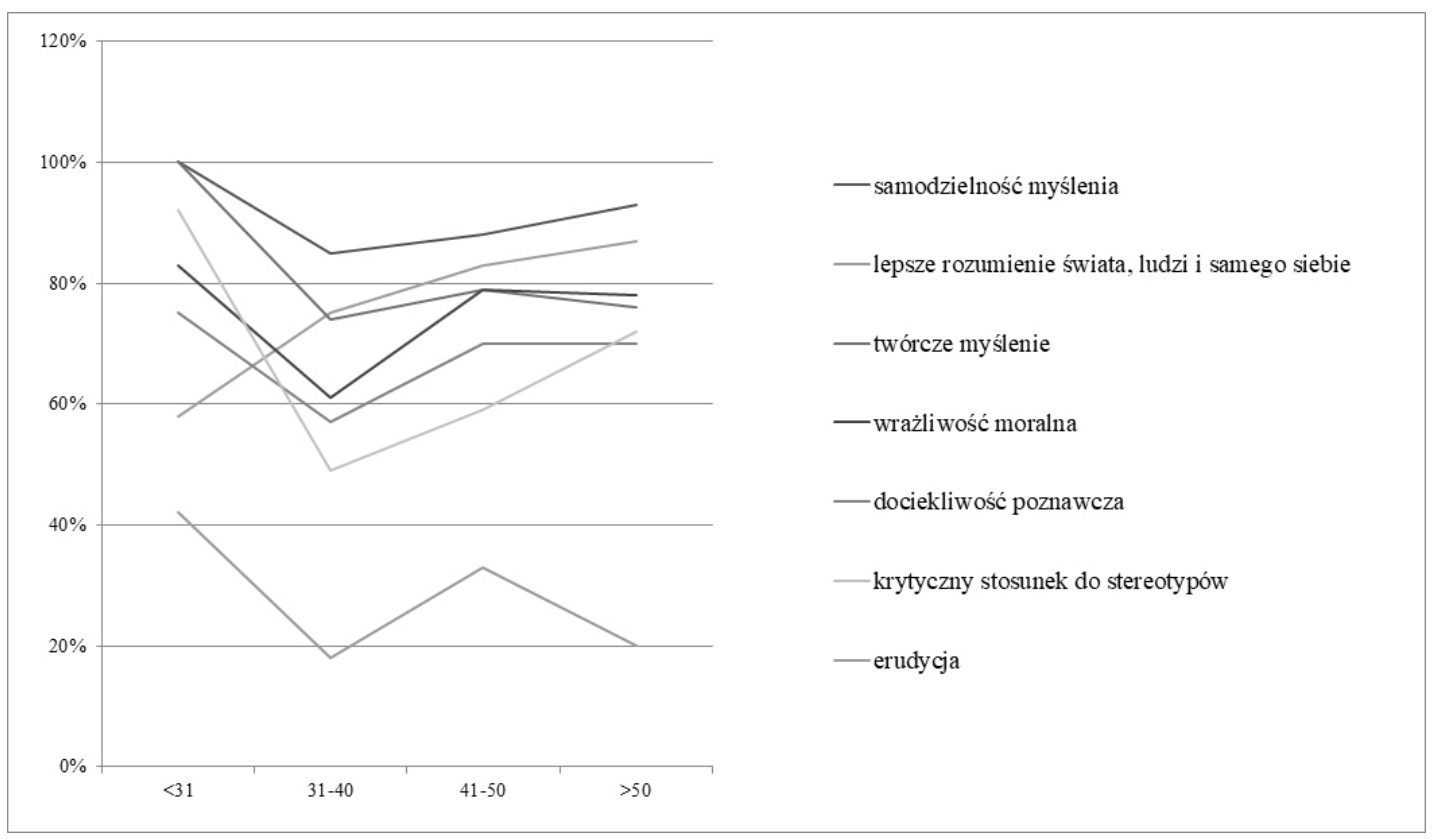

Źródło: oprac. własne.

Wykres 4. Powody nauczania filozofii. Wyniki odpowiedzi dyrektorów na pytania wielokrotnego wyboru: „Z jakich powodów wprowadzono do Pani/Pana szkoły nauczanie filozofii? Proszę wybrać wszystkie odpowiedzi, które pasują” oraz „Z jakich powodów obecnie naucza się w Pani/Pana szkole filozofii? Proszę wybrać wszystkie, które pasują", N=206

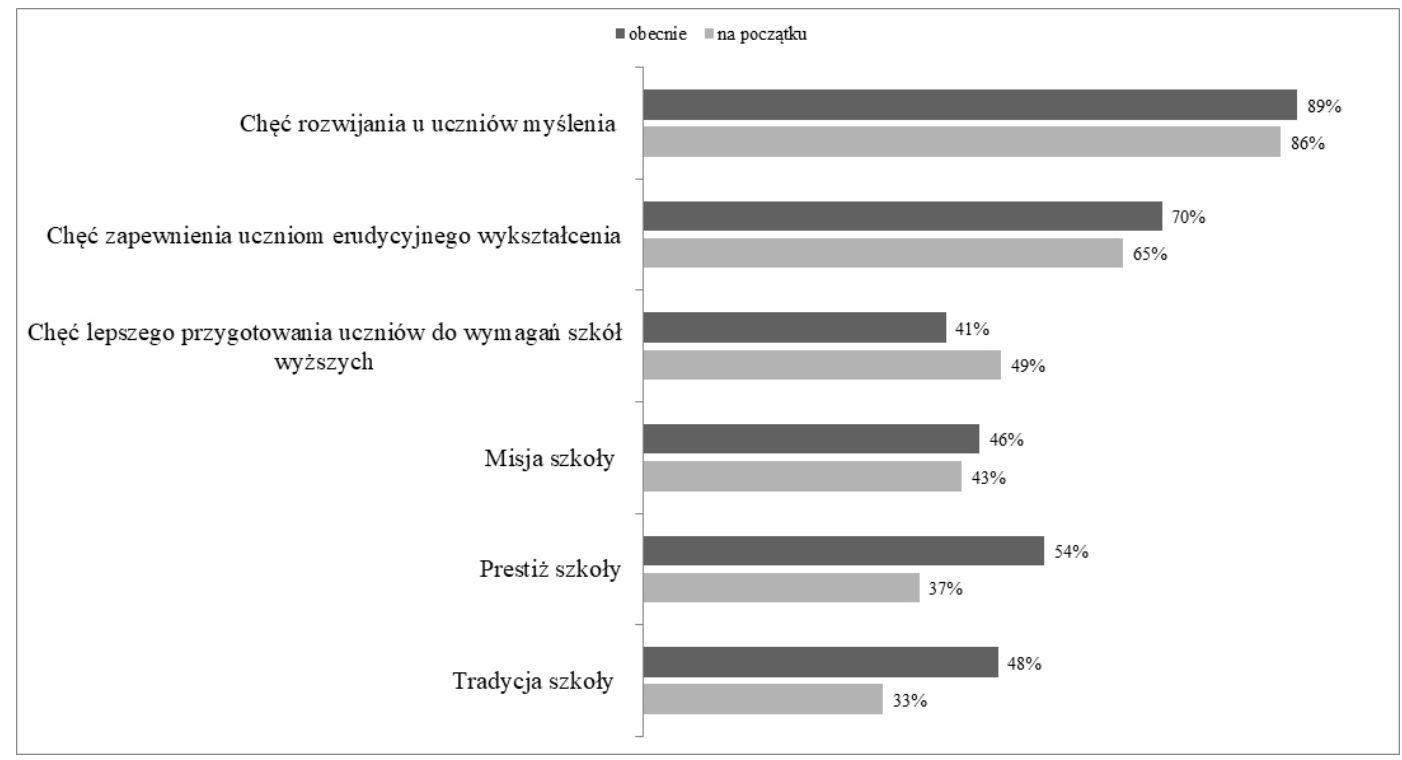

Źródło: raport IBE: Trepczyński i in. 2015. 
Prezentację wyników ilościowych warto domknąć danymi pochodzącymi z raportu $z$ badania, a dotyczącymi opinii dyrektorów co do powodów nauczania filozofii. Zgodnie nimi 65 proc. dyrektorów uznało, że chęć zapewnienia uczniom erudycyjnego wykształcenia była jednym z powodów wprowadzenia nauczania filozofii do ich szkoły. Zarazem 70 proc. dyrektorów stwierdziło, że jest to jeden $\mathrm{z}$ powodów, dla którego w chwili badania nadal nauczano w ich szkole filozofii. Zestawienie wszystkich odpowiedzi dyrektorów dotyczących powodów nauczania filozofii przedstawiono na wykresie 4. Wybierane przez dyrektorów odpowiedzi zostały sformułowane na podstawie wyników badania pilotażowego.

\section{Dyskusja wyników ilościowych}

Chociaż tylko 25 proc. respondentów zaliczyło erudycję do grupy celów, które „przede wszystkim powinny być celami nauczania filozofii w szkole”, nie można stwierdzić, że pozostali ankietowani nie doceniają erudycji jako celu edukacji filozoficznej. Potwierdzają to szczegółowe dane, zgodnie z którymi wskazań „o”, „1" i „2” było w sumie 40 (czyli 20 proc.). Pozostałe odpowiedzi (8o proc.) można uznać za pozytywne odniesienie się do erudycji (co więcej, mediana dla podanych wartości wynosi 4).

Zarazem jednak wykres 2 pokazuje, że w porównaniu z innymi celami ogólnymi erudycja jest oceniana zdecydowanie gorzej. Nie tylko uzyskała ponad dwa razy mniej wskazań o wartości „5”, lecz także uzyskała najwięcej wskazań „o” i „” (w sumie) oraz zdecydowanie więcej niż pozostałe wskazań „„”, a zatem lokowana jest zdecydowanie niżej niż pozostałe cele. Jeśli zaś wziąć pod uwagę dominanty, to erudycja jest jedynym celem, dla którego najwięcej respondentów przypisało wartość „3" (wszystkim innym najwięcej przypisało „5”). Dodatkowo, rozkład odpowiedzi dla wszystkich tych celów układa się w ciąg rosnący z maksimum dla „5”; jedynie w przypadku erudycji ciąg ten jest niemonotoniczny z maksimum w okolicy środka.

Można więc uznać, że erudycja jest ceniona przez większość respondentów (nawet przez 8 o proc.) jako cel nauczania filozofii, jednak nie jest według tej grupy tak ważna, jak wszystkie pozostałe wymienione cele. Z pewnością jednak nie można uznać, że została ona odrzucona jako cel nauczania filozofii, albowiem tylko jeden respondent przypisał jej wartość „o”, co należałoby uznać za znak sprzeciwu wobec takiego celu, i tylko jeden nie udzielił odpowiedzi, co w treści pytania uznano za równoważne odpowiedzi „o”, mimo to trudno uznać to za wyraźny sprzeciw.

Analiza grupy, która uznała erudycję za jeden z najważniejszych celów nauczania filozofii, pokazuje, że trudno byłoby doszukiwać się związku między tym wyborem a płcią lub rodzajem szkoły. Pewnej zależności można się natomiast dopatrywać w przypadku miejscowości, w której uczą respondenci, a także ich wieku.

Jeśli chodzi o miejscowość, to dało się zauważyć, że wśród respondentów, którzy przypisali erudycji wartość „5”, jest stosunkowo wyraźnie mniej nauczycieli 
z Warszawy, czego jednak trudno się doszukać w innych dużych miastach (różnica jednego punktu proc.), a więcej nauczycieli z miast średniej wielkości. Może to stanowić podstawę do zbadania przyczyn, dla których erudycja została bardziej doceniona przez nauczycieli właśnie z tych ośrodków.

Jeśli zaś wziąć pod uwagę wiek, to najwyższy procent wskazań „5” odnotować można wśród najmłodszych respondentów (poniżej 31 roku życia). Jest on ponad dwukrotnie wyższy niż u respondentów o 10 lat starszych (31-40 r. ż.), którzy najrzadziej przypisywali erudycji wartość „5”. Kolejna grupa (41-50 r. ż.) znów stosunkowo często przypisuje erudycji wartość „5”, po czym w grupie najstarszej (powyżej 5 r. ż.) także notuje się spadek oceny, prawie do poziomu z grupy 30-latków.

Można więc zauważyć, że spośród nauczycieli filozofii najbardziej docenia erudycję najmłodsze pokolenie. Ponadto wyniki w kolejnych grupach mogą sugerować istnienie związku między grupami 20-latków i 40-latków oraz między grupą 30-latków i grupą najstarszych nauczycieli; mianowicie można postawić hipotezę, że pokolenie 20-latków, do których w chwili badania należeli najmłodsi nauczyciele, a także pokolenie ich rodziców (2o lat starsi), jest lepiej nastawione do takich wartości, jak erudycja niż pokolenie ówczesnych 30-latków i ich rodziców.

Należy rozważyć, czy podobnie kształtują się wyniki dla innych celów ogólnych. Wykres 4 pokazuje, że dla w większości celów grupa 31-40-latków okazywała się najbardziej sceptyczną (najrzadziej przypisywała erudycji wartość „5”), aczkolwiek nie jest to regułą: „Lepsze rozumienie świata, ludzi i samego siebie” znacznie rzadziej od nich wybierali najmłodsi nauczyciele. Wykres ten pokazuje też, że podobny przebieg ciągu w przypadku erudycji (malejąco-rosnąco-malejący) można zaobserwować tylko w przypadku takich celów, jak wrażliwość moralna i twórcze myślenie, aczkolwiek różnice w procentowym udziale wskazań „5” $\mathrm{W}$ starszych grupach nie są tak wyraźne, jak w przypadku erudycji. A zatem przeciwko hipotezie tej nie można wysunąć tezy, jakoby kolejne grupy wiekowe przypisywały wartość „5” zgodnie z ogólnym (bardziej lub mniej pozytywnym) nastawieniem do jakichkolwiek celów ogólnych. Hipotezy tej nie można w ten sposób obalić, jednak zebrane dane nie wystarczają, aby ją potwierdzić.

Na koniec warto zauważyć, że zdecydowanie pozytywnie do erudycji odnieśli się dyrektorzy szkół. Siedemdziesiąt proc. z nich wskazało na zapewnienie uczniom erudycyjnego wykształcenia jako jeden z powodów, dla których w chwili badania nadal utrzymywali w szkole nauczanie filozofii. Być może jednak wpisuje się to w założenie, aby ujawniając motywy swoich decyzji, przede wszystkim odwoływać się do dobra ucznia, wiązanego z jego kształtowaniem, co potwierdzałoby wskazanie jako innego powodu nauczania filozofii w szkole „chęci rozwijania u uczniów myślenia" przez 89 proc. respondentów.

Chociaż zarówno dyrektorzy, jak i nauczyciele filozofii odnieśli się do pojęcia erudycji w kontekście uzasadnienia prowadzenia edukacji filozoficznej, należy zauważyć, że ze względu na odmienność pytań, zestawu podanych opcji oraz 
sposobu udzielania odpowiedzi trudno porównać uzyskane wyniki. Można jednak doszukiwać się zbieżności, jeśli uzna się, że wskazania nauczycieli o wartości „3-5” (8o proc. respondentów) to uznanie erudycji jako ważnego celu nauczania filozofii; korespondują one z odpowiedziami dyrektorów, spośród których 70 proc. uznało, że jednym z powodów prowadzenia edukacji filozoficznej jest chęć zapewnienia uczniom erudycyjnego wykształcenia.

\title{
Komponent jakościowy
}

\section{Przeciwko „uczeniu”, „historii filozofii” i „regułkom”}

Niektórzy dyrektorzy i nauczyciele podczas wywiadów pogłębionych dali wyraz przekonaniu, że edukacja filozoficzna nie powinna przeradzać się w uczenie historii filozofii czy też przekazywanie informacji o koncepcjach filozoficznych. Według poniższych wypowiedzi dwóch dyrektorów taki model wiąże się z brakiem zaangażowania nauczyciela i znudzeniem ze strony uczniów:

\begin{abstract}
Ale jak tu uczymy się regułkami, np.: Arystoteles to to, Platon to to, Hegel to to, to jest to przyswajanie kolejnego materiału, który jest tylko kolejną dawką, porcją informacji. Natomiast ja uważam, że filozofia może nauczyć dostrzegania piękna, postrzegania w odpowiedni sposób świata, czy i jakie są możliwości doświadczania świata, a nie to, że ktoś stworzył jakąś regułkę i miał jakąś myśl, i to jest kolejne odfajkowanie elementu programu, który został stworzony (dyrektor, L, w4) ${ }^{10}$.

(...) jeżeli zrobi się historię filozofii, to po pewnym czasie dzieci znudzą się postaciami. Jeżeli byłaby to historia filozofii, to uczniowie po jakimś czasie odbiorą to jako naukę skostniałą, to będą tylko postaci (dyrektor, GL, w12).
\end{abstract}

Jeśli by więc znajomość koncepcji filozofów uznać za istotny element erudycji, to wydaje się, że tak rozumianej erudycji respondenci są przeciwni. Wygląda na to, że ich zdaniem takie podejście pozbawia filozofię jej właściwych walorów, które w pierwszej wypowiedzi określono jako naukę szerszego postrzegania rzeczywistości.

$\mathrm{Z}$ opiniami tych dwóch dyrektorów koresponduje stanowisko nauczyciela filozofii, który jest przeciwny nauczaniu historii filozofii, chronologicznemu porządkowaniu zagadnień, a nawet ukazywaniu kontekstu historycznego prezentowanych koncepcji:

10 W podpisach cytatów przyjęto następujące skróty: $L$ - liceum, $G$ - gimnazjum, $G L$ - gimnazjum i liceum, $w$ - województwo (dodano przyporządkowany indeks zamiast nazwy województwa ze względu na konieczność anonimizacji respondentów). 
Według mnie bardzo złym i fałszywym nastawieniem jest przypisywanie filozofii roli przedmiotu humanistycznego. Filozofia chyba nigdy nie była przedmiotem humanistycznym. W związku z tym można się zastanawiać, czy jest społecznym, czy jest ścisłym. W związku z tym dla mnie zupełnie niepotrzebnymi elementami są nawiązania do kontekstu historycznego. Historyczny czy chronologiczny sposób przyswajania wiedzy filozoficznej to jest zupełnie poroniony - według mnie - pomysł. On nic nie uczy oprócz historii filozofii. W związku z tym jest suchy. Nie ma tam mięsa, jak to ostatnio jedna pani profesor powiedziała, same kostki i nie ma co ugryźć (nauczyciel, L, w8).

Jak widać, pogląd swój wiąże on z przekonaniem, że uwzględnianie elementu historycznego w filozofii jest ściśle połączone $z$ traktowaniem filozofii jako przedmiotu humanistycznego. Wygląda na to, że jest on przeciwny elementom erudycji, jakimi byłyby informacje historyczne związane z poszczególnymi koncepcjami filozoficznymi i ich autorami.

\section{Erudycja jako podstawa do rozwijania i kształtowania siebie}

Duża część respondentów wskazywała w wywiadach, że uczniowie powinni poznawać różne zagadnienia i rozwiązania stawiane przez filozofów, aby dzięki temu zastanawiać się i samodzielnie wyrabiać własne poglądy:

Filozofia (...) ma do tego służyć, żeby uczniowie wyrabiali poglądy, żeby mogli poznać różne myśli, różnych myślicieli, to po pierwsze (dyrektor, $G, w 7)$.

Zaczynając od najniższego poziomu, [filozofia] powinna dawać dzieciom bazę, do której mogą się odwołać, stawiając pytania. Widziałabym tutaj rolę nie tyle edukacyjną, co wychowawczą, ale na tej zasadzie, żeby oni wiedzieli, że ludzie zawsze się dręczyli, zawsze zadawali sobie różne pytania, że te pytania są do siebie bardzo podobne na przestrzeni wieków, a tylko doświadczenia się zmieniają. W związku z tym muszą jakoś odpowiedzieć na te doświadczenia (nauczyciel, L, w6).

Podobnie wypowiada się nauczyciel, który zarazem podkreśla rolę historii filozofii jako ilustracji wciąż ewoluującej myśli, stawiając się w opozycji do zaprezentowanych wyżej poglądów przeciwników ujęcia historycznego:

...I oczywiście historia filozofii: (...) jak myśl się rozwija, pokazując, że to jest taka myśl w ruchu (takie dzieje myśli), że to jest coś pięknego, ten rozwój, dojrzewanie, pewne zmiany. To też ich fascynuje. Tylko trzeba im wyjaśnić: "Pamiętajcie, że to ma was rozwijać, ma was skłonić do myślenia” (nauczyciel, G, w7). 
W podobnym duchu wypowiedział się dyrektor, który erudycję humanistyczną i historię filozofii opartą na źródłach wiąże z rozwijaniem myślenia, co zastępuje np. współcześnie modne metody pracy nad rozwojem własnym:

Myślę, że niezbędne jest trochę popracowanie z tekstami źródłowymi, krótko mówiąc z tą historią filozofii, ale generalnie jest to myślę świetna nauka filozoficznego myślenia o życiu, i niepotrzebne są wtedy żadne współczesne modne obecnie coaching itp. Zamiast tego: logiczne myślenie (bardzo fajnie tutaj logika wchodzi przy filozofii), no i coś, co nazwałabym ogólnie erudycją humanistyczną (dyrektor, L, w8).

Zaznaczmy jednak, że wśród wspomnianych przeciwników przynajmniej jeden również wyraźnie opowiedział się za rolą filozofii jako narzędzia do kształtowania dojrzałej osobowości, konsekwentnie odżegnując się jednak od ujęcia historycznego oraz informacji, z którymi zazwyczaj wiąże się pojęcie erudycji:

Ona powinna być takim ogólnym przygotowaniem do bycia człowiekiem, obywatelem, nie wiem, taką dojrzałą osobą. I w tym sensie do tego powinna prowadzić, czyli niekoniecznie historia filozofii, tylko raczej rozwiązywanie problemów, z którymi się stykamy, bardziej filozofia... (nauczyciel, L, w8).

Za prezentowaniem „ścieżek” i wyborów różnych filozofów jako podstawie do rozwoju osobistego, opowiedział się respondent, który edukację filozoficzną powiązał z programem terapeutycznym:

W programie terapeutycznym chodzi o pokazanie tego, jak rozwijały się ścieżki danych filozofów, w jaki sposób oni dokonywali wyborów życiowych. Terapia ma polegać na pokazaniu młodemu uczniowi różnorodności wyborów, że każda metoda jest inna, ale też że nie można ciągle zmieniać wyborów i dopuścić do tego, że dwudziestokilkuletni człowiek zastanawia się, kim będzie w życiu (dyrektor, L, w6).

\section{Erudycja a kompletność wykształcenia}

Jeden z pytanych dyrektorów zwrócił uwagę, że filozofia jest niezbędna w kontekście integralnego rozwoju ucznia:

Jeśli przyjmiemy, że celem głównym szkoły jest integralny rozwój ucznia, to filozofia jest tym elementem, który składa się na tę kompletność, na tę całość, na to spojrzenie i budowanie dojrzałości w każdym człowieku (...) (dyrektor, L, w5). 
Nie sposób jednak rozstrzygnąć, czy z edukacją filozoficzną wiązał on tu erudycję w tym zakresie.

Inni jednak wprost wskazywali, że filozofia wpisuje się w potrzebne ich zdaniem poszerzenie oferty edukacyjnej o charakterze humanistycznym:

Przede wszystkim jest to rozszerzenie bloku przedmiotów humanistycznych. Liceum ogólnokształcące w samej swej istocie powinno w jak najszerszym stopniu dostarczać możliwości rozszerzania oferty edukacyjnej (dyrektor, L, W2).

Jeden z nich odwoływał się dodatkowo do europejskiego kodu kulturowego:

(...) nauczanie filozofii przyczyni się do lepszego, bardziej pogłębionego, bogatego kształcenia humanistycznego. Że będzie nie tylko poszerzało wiedzę uczniów o bardzo ważne zagadnienia, których uczenia wymaga podstawa programowa $z$ filozofii. Nie tylko poznawanie. Kiedyś mówiono o jakimś kodzie kulturowym, który jest wpisany w cywilizację europejską i bez tego nie ma mowy o prawdziwej humanistyce. Czyli pogłębione, poszerzone kształcenie humanistyczne. Jestem pewien, że wprowadzenie filozofii temu będzie dobrze służyć (dyrektor, L, w10).

W wypowiedzi tej mowa jest więc o erudycji w głębokim znaczeniu, odwołującej się nie do samej wiedzy, ale - w świetle tej wiedzy - do rozumienia m.in. kultury.

\section{Wiedza z umiejętnościami, czyli zastosowanie wiedzy}

Dla wielu respondentów wiedza związana z edukacją filozoficzną ma sens wyłącznie w kontekście jej zastosowania, czyli w przypadku, gdy zarazem rozwijane są umiejętności uczniów. Ilustruje to m.in. poniższa wypowiedź:

(...) nauczenie się samej regułki nie rozwija człowieka. On musiałby ją wykorzystać w sposób doświadczalny, czy potrafić opisać, odnieść (dyrektor, L, w4).

Jeszcze dobitniej ujął to inny dyrektor:

Według mnie nie ma w ogóle sensu żaden przedmiot, który tylko przekazuje informacje. Jeżeli uczeń widzi, że wykorzystuje te umiejętności, które zdobywa na lekcji i że to daje mu jakąś korzyść, to on z chęcią się tego uczy. Ja nie twierdzę, że nie można nic z historii filozofii powiedzieć, oczywiście, że tak, trzeba, ale to nie może być taki przedmiot suchy, muszą być debaty, muszą być dyskusje, muszą być rozważania, argumentowania, logiczne myślenie, to musi być, to jest istotą tego przedmiotu. Jasne, że tak, uczniowie muszą wiedzieć, 
jak to się rozwijało przez wieki. Czasem spotykam się z tym, że oni przytaczają słowa jakichś filozofów, co mnie bardzo cieszy, (...) ale umiejętności miękkie we współczesnym świecie są najbardziej potrzebne, a one mogą być ćwiczone i zdobywane na tym przedmiocie (dyrektor, GL, w12).

Inny dyrektor na pytanie o cel takiej edukacji odpowiedział:

Cel? Poszerzenie wiadomości i umiejętności dotyczących filozofii, ale też taka możliwość rozwijania innych umiejętności, jak właśnie logiczne myślenie, jak myślenie twórcze, a także poznanie tych prawd, które dawni filozofowie gdzieś tam przedstawiali (dyrektor, G, w16).

W jednym $\mathrm{z}$ wywiadów wspomniano też o dwóch konkretnych potrzebnych uczniom umiejętnościach rozwijanych wraz z erudycją, czyli łączeniu wiedzy z różnych dyscyplin oraz dokonywania własnych ocen:

Dla mnie też ważna jest, bo jestem nauczycielem historii, umiejętność korelowania, czyli umiejętność łączenia, z którą uczniowie mają problem, wiedzy historycznej, wiedzy filozoficznej, wiedzy z języka polskiego, z literatury. (...) Uczeń, kiedy stawia się mu problem filozoficzny, zauważa, że można dywagować na dany temat. Widzi, że nie ze wszystkim może się godzić. Słyszy, jak to klasyk określał dane wydarzenie i on ma też możliwość dokonania własnej oceny i snucia swoich teorii (dyrektor, L, w2).

Z kolei jeden z nauczycieli filozofii wiąże rozwijanie kultury dyskusji z wiedzą o różnorodności poglądów i postaw, m.in. w różnych epokach:

Filozofia powinna uczyć myślenia, w takim znaczeniu, żeby nie schodzić na manowce, to znaczy, żeby nie stosować dyskusji i metod, które opierają się na obrażaniu, poniżaniu oraz żeby wiedzieć, że człowiek musi mieć odrębne zdanie i umieć formułować to swoje zdanie. Żeby młodzi ludzie mieli świadomość, że postaw jest wiele i są one porównywalne i należy się szacunek tym postawom. (...) Zależy mi, żeby młodzi ludzie wiedzieli, jaki jest dorobek i jak wiele wynika z epoki oraz jej stylu (nauczyciel, L, w6).

\section{Ku klasycznemu wykształceniu}

W wywiadach pojawiły się również wypowiedzi dyrektora i nauczyciela (z różnych województw), w których w pozytywnym świetle mówi się o filozofii jako elemencie klasycznego, „przedwojennego” wykształcenia, wyraźnie nawiązując do zapewniania uczniom erudycji: 
Na pewno było to jakieś wzorowanie się na tym wykształceniu, powiedzmy, przedwojennym, gdzie retoryka, filozofia, łacina to było klasyczne wykształcenie. I myślę, że jako szkoła katolicka zawsze mieliśmy takie inklinacje do takiego klasycznego liceum, gdzie ta filozofia miała swoje miejsce (dyrektor, L, w5).

Trzeba byłoby wrócić do dobrych starych tradycji. Wrócę do tego modelu francuskiego albo lepiej: do polskiego przedwojennego. Może to stereotypy, że była to szkoła, która kształciła inteligentnych, myślących erudytów, [ale] są na to dowody. Pewnie Gombrowicz w Ferdydurke pokazał inne oblicze szkoły przedwojennej. Czy ona była atrakcyjna, czy nudna - to już inna sprawa (nauczyciel, L, w14).

W takim podejściu zapewnienie uczniom erudycyjnego wykształcenia jawi się jako jeden z wyraźnych celów nauczania filozofii.

\section{Podsumowanie}

Wyniki ilościowe pokazały, że wśród podanych celów ogólnych nauczania filozofii erudycja została oceniona przez nauczycieli filozofii najniżej i zarazem znacznie niżej niż inne cele. Jednocześnie wyniki te nie wskazują na negatywną ocenę erudycji, lecz raczej na to, że wśród tych celów schodzi ona na dalszy plan. Ocena ważności tego celu nie zależy od płci respondenta czy rodzaju szkoły, w którym on naucza, aczkolwiek widać pewną zależność tej oceny od wielkości miejscowości, w której znajduje się szkoła respondenta. Dało się wreszcie zauważyć zależność wyników od wieku respondentów, z których najmłodsi (a także pokolenie ich rodziców) oceniali ją jako jeden z najważniejszych celów znacząco częściej niż ich koledzy o 10 lat starsi oraz pokolenie ich rodziców.

Natomiast zdecydowana większość dyrektorów uznała, że chęć zapewnienia uczniom erudycyjnego wykształcenia była jednym z głównych powodów, dla których wprowadzono filozofię do szkoły i dla których kontynuuje się jej nauczanie.

Wywiady pogłębione $\mathrm{z}$ dyrektorami i nauczycielami ujawniły obawę przed czysto „wiedzowym” nauczaniem filozofii. Niektórzy w nauczaniu poglądów poszczególnych filozofów widzieli wręcz zagrożenie, ponieważ w ich mniemaniu zdaje się ono odciągać od głównego celu, jakim jest np. poszerzanie spojrzenia, zarazem przeciążając uczniów informacjami, lub powoduje ono znudzenie i niechęć do przedmiotu.

W wielu przypadkach respondenci zdawali się odwoływać do erudycji jako czegoś głębszego, związanego z rozumieniem, rozwojem i umiejętnościami. W szczególności wspomniano o takich umiejętnościach, jak: rekonstruowanie konkretnego poglądu, stosowanie wiedzy w konkretnej sytuacji, łączenie wiedzy $\mathrm{z}$ wielu dyscyplin, dokonywanie własnej oceny oraz branie udziału w dyskusji 
z poszanowaniem innych poglądów i postaw. W wypowiedziach odnoszących się do własnego rozwoju, w tym rozwoju osobowości, na pierwszy plan zdaje się wybijać spostrzeżenie, że poznanie różnorodnych poglądów filozoficznych pomaga wyrobić samodzielnie własne poglądy oraz jest bazą do formułowania pytań Ciekawe wydaje się tu również przekonanie, że wspomniana różnorodność ukazuje uczniom wielość możliwości wyboru czy wielość sytuacji, w których można tego wyboru dokonać, zarazem jednak ucząc konsekwencji, rozumianej jako trwanie przy podjętej decyzji. W niektórych przytoczonych wypowiedziach widać też przekonanie, że głębiej rozumiana erudycja filozoficzna jest potrzebna do uzupełnienia humanistycznego wykształcenia, mającego dostarczyć całościowego spojrzenia na kulturę. Stąd też prawdopodobnie dwóch uczestników wywiadów nawiązało do tradycyjnego wykształcenia, określanego jako „klasyczne”.

W kontekście tych wypowiedzi widać, że wyniki ilościowe mogły zależeć od tego, czy respondenci rozumieli erudycję wąsko (jako czysto informacyjny „bagaż”), czy też wiedzę mającą przełożenie na rozumienie i rozwój w zakresie osobowości lub umiejętności. W takim wypadku mogłoby to wskazywać na kryzys pojęcia „erudycja” w tym sensie, że przestało ono być komunikacyjnie efektywne. Warto więc podjąć wysiłki ku temu, aby „naprawić je” w dyskursie społecznym, dookreślając jego znaczenie w stosunku do innych celów edukacji.

W kontekście upatrywania przez wielu respondentów wielkiej wartości w uczeniu samodzielnego myślenia, a także rozwijaniu osobowości oraz umiejętności, widać bowiem, że przynajmniej uczestnicy wywiadów doceniają erudycję określoną tu roboczo jako „głęboką”, co nie oznacza rozległości i szczegółowości zdobywanej wiedzy, lecz odnosi się do stopnia jej zrozumienia i jej przełożenia na rozwój człowieka, który ją posiadł. Wydaje się, że chodzi im o taką erudycję, w ramach której wiedza będzie w uczniu pracować, będzie skłaniać go do zadawania pytań, będzie otwierać oczy na nieznane mu dotąd możliwości, będzie materiałem do własnych analiz, a zarazem kluczem do lepszego zrozumienia otaczającego świata, w tym kultury.

\section{Bibliografia}

Arystoteles (2003). Metafizyka, tłum. K. Leśniak. W: Arystoteles. Dzieła wszystkie. T. 2. Warszawa: Wydawnictwo PWN.

Erudycja (2018). W: Słownik Języka Polskiego, dostępny na: https://sjp.pl/erudycja (otwarto: 4.01.2018).

Erudition (2018a). W: Oxford Advanced Learner's Dictionary, dostępny na: https:// www.oxfordlearnersdictionaries.com/definition/english/erudition?q=erudition (otwarto: 4.01.2018).

Erudition (2018b). W: Oxford British \& World English, dostępny na: https:// en.oxforddictionaries.com/definition/erudition (otwarto: 4.01.2018). 
Gajdamowicz H. (2012). Tradycje nauczania wychowującego w polskiej pedagogice. "Paedagogia Christiana”, 1 (29), s. 123-140.

Marciniak Z. (2008). O potrzebie reformy programowej kształcenia ogólnego. W: Podstawa programowa wychowania przedszkolnego oraz kształcenia ogólnego. T. 2. Warszawa: Ministerstwo Edukacji Narodowej.

MEN (2017a). Podstawa programowa kształcenia ogólnego dla 4-letniego liceum ogólnokształcącego i 5-letniego technikum (projekt), dostępny na: https://legislacja.rcl.gov.pl/docs//501/12300604/12446876/12446877/dokument299323.pdf (otwarto: 4.01.2018).

MEN (2017b). Rozporządzenie Ministra Edukacji Narodowej z dnia 14 lutego $2017 \mathrm{r}$. $w$ sprawie podstawy programowej wychowania przedszkolnego oraz podstawy programowej kształcenia ogólnego dla szkoły podstawowej, w tym dla uczniów $z$ niepełnosprawnościa intelektualna $w$ stopniu umiarkowanym lub znacznym, kształcenia ogólnego dla branżowej szkoły I stopnia, kształcenia ogólnego dla szkoły specjalnej przysposabiajacej do pracy oraz kształcenia ogólnego dla szkoły policealnej (Dz.U. z 2017 roku, poz. 356).

MEN (2012a). Rozporządzenie Ministra Edukacji Narodowej z dnia 7 lutego 2012 r. $w$ sprawie ramowych planów nauczania w szkołach publicznych (Dz.U. z 2012 roku, poz. 204 ze zm.)

MEN (2012b). Rozporządzenie Ministra Edukacji Narodowej z dnia 27 sierpnia $2012 \mathrm{r}$. $w$ sprawie podstawy programowej wychowania przedszkolnego oraz kształcenia ogólnego w poszczególnych typach szkół (Dz.U. z 2012 roku, poz. 997 ze zm.).

Nawroczyński B. (1946). Zasady Nauczania. Warszawa-Wrocław-Kraków: Książnica - Atlas.

Platon (2002). Teajtet, tłum. W. Witwicki. W: Platon, Parmenides, Teajtet. Kęty: Wydawnictwo Marek Derewiecki.

Pobojewska A. (2012). Początek filozofii: podstawy, motywacje, umiejętności. W: Pobojewska A. (red.). Filozofia. Edukacja interaktywna. Metody-środkiscenariusze. Warszawa: Wydawnictwo Piotra Marciszuka Stentor.

Shor I. (1992). E-powering Education. Critical Thinking for Social Change. ChicagoLondyn: University of Chicago Press.

Szymański M. (2014). Nowa podstawa programowa nauczania filozofii a modyfikacja celów dydaktycznych i sposobów ich realizacji. „Studia Philosophiae Christianae UKSW", 4 (50), s. 191-207.

Trepczyński M., Stanaszek A., Grudniewska M., Gmaj I. (2015). Nauczanie filozofii na III i IV etapie edukacyjnym. Warszawa: Instytut Badań Edukacyjnych.

Wierzbicki A.M. (2005). Filozofia a totalitaryzm. Augusta Del Nocego interpretacja kryzysu moderny. Lublin: Katolicki Uniwersytet Lubelski. 


\title{
ERUDITION AS AN OBJECTIVE OF SCHOOL PHILOSOPHICAL EDUCATION
}

\begin{abstract}
Erudition can be one of objectives of school philosophical education. Philosophy teachers in secondary schools in Poland who in 2014 took part in a nationwide research on teaching philosophy in lower and upper secondary schools (data were collected from $88 \%$ of headmasters from all the schools in Poland where philosophy was taught and $79 \%$ of teachers from these schools), asked to assess the importance of several educational objectives within philosophical education (on the scale 0-5), gave a relatively low rating to erudition. Despite this fact teachers to some extent appreciate erudition as a goal of philosophical education, which corresponds with the answers of the headmasters. The interviews conducted with 15 teachers and 15 headmasters show that they appreciate erudition in a deeper meaning, which is not a purely "encyclopedic" knowledge, but refers to a well understood knowledge being a basis for personal development, skills development and a starting point for posing questions.
\end{abstract}

Key words: philosophy, philosophy teaching, school philosophical education, erudition, teaching objectives, learning outcomes, knowledge, skills.

Marcin Trepczyński - dr nauk humanistycznych w zakresie filozofii, mgr prawa i mgr filozofii, adiunkt w Instytucie Filozofii Uniwersytetu Warszawskiego. Autor monografii pt. Ścieżki myślenia Alberta Wielkiego i Tomasza z Akwinu (Warszawa, 2013), współautor i redaktor monografii pt. Nauczanie filozofii na III i IV etapie edukacyjnym (Warszawa 2015), będącej raportem $\mathrm{z}$ badania przeprowadzonego w Instytucie Badań Edukacyjnych. Adres do korespondencji: Instytut Filozofii UW, ul. Krakowskie Przedmieście 3, oo-047 Warszawa. Adres e-mailowy: m.trepczynski@uw.edu.pl. 